O'Brien, J. R. (1956). J. clin. Path. 9, 47.

Parreira, H. C. \& Pethica, B. A. (1957). 2nd Int. Congr. Surface Activity, London. London: Butterworths Scientific Publications.

Pethica, B. A. \& Schulman, J. H. (1953). Biochem. J. 53, 177.

Robinson, R. A. \& Stokes, R. H. (1955). Electrolyte Solutions. London: Butterworths Scientific Publications.
Seaman, G. V. F. \& Pethica, B. A. (1957). 2nd Int. Congr. Surface Activity, London. London: Butterworths Scientific Publications.

Verwey, E. J. W. \& Overbeek, J. T. C. (1948). Theory of the Stability of Myophobic Colloids. Amsterdam: Elsevier.

Winkler, K. C. \& Bungenberg de Jong, H. G. (1940-41). Arch. néerl. Physiol. 25, 431.

\title{
Fungal Detoxication
}

\section{THE METABOLISM OF $\omega$-(2-NAPHTHYLOXY)- $n$-ALKYLCARBOXYLIC ACIDS BY SCLEROTINIA LAXA*}

\author{
By R. J. W. BYRDE AND D. WOODCOCK \\ Long Ashton Research Station, University of Bristol
}

(Received 20 August 1957)

The metabolism of $\omega$-(2-naphthyloxy)-n-alkylcarboxylic acids by Aspergillus niger van Tiegh. has been described in an earlier paper in this series (Byrde, Harris \& Woodcock, 1956). By means of a replacement-culture technique it was shown that the acids were hydroxylated in position 6 of the naphthalene nucleus, and that higher members underwent $\beta$-oxidation.

The present paper describes an extension of the work to the plant pathogenic fungus Sclerotinia laxa Aderh. \& Ruhl., the organism causing the brown-rot and blossom-wilt diseases of fruit trees.

\section{EXPERIMENTAL}

The materials and reference compounds have already been described (Byrde et al. 1956).

\section{Methods}

Replacement culture and isolation of metabolites. The method used followed that already described (Byrde et al. 1956), with the following modifications. Cultures of $S$. laxa, originally isolated from sour cherry, were grown on a liquid medium composed of: glucose, $40 \mathrm{~g}$.; peptone, $10 \mathrm{~g}$; $\mathrm{KH}_{2} \mathrm{PO}_{4}, 6.8 \mathrm{~g}$.; $\mathrm{MgSO}_{4}, 7 \mathrm{H}_{2} \mathrm{O}, 2.5 \mathrm{~g}$.; $\mathrm{CaCl}_{2}, 0.1 \mathrm{~g}$.; $\mathrm{FeCl}_{3}, 0.02 \mathrm{~g}$.; water to $1 \mathrm{l}$. The medium was dispensed in $50 \mathrm{ml}$. lots in $20 \mathrm{oz}$. medicinal 'flats' and sterilized (10 lb./ sq.in. for $20 \mathrm{~min}$.). Each bottle was inoculated with 6 disks (4 mm. in diameter) of mycelium cut from an established culture on solid medium, and incubated at $25^{\circ}$ for 7 days. The medium was then replaced by $100 \mathrm{ml}$. of a solution of the test acid $(0.5 \mathrm{~mm})$ in $0.01 \mathrm{M}-\mathrm{Na}_{2} \mathrm{HPO}_{4}$. After a further 7 days the substrate was poured off, extracted with ether and examined chromatographically.

Fungitoxicity in vitro. Fungistatic activity was assessed by the rate of mycelial growth of S. laxa on an agar medium in which the compounds under test were incorporated. The

* Part 2: Byrde \& Woodcock (1957). liquid medium described above, with the addition of agar $(3 \%, \mathrm{w} / \mathrm{v})$, was dispensed in $50 \mathrm{ml}$. lots in $100 \mathrm{ml}$. flasks and autoclaved (10 lb./in. ${ }^{2}$ for $20 \mathrm{~min}$.). The $\mathrm{pH}$ was adjusted as necessary, after autoclaving, by the addition to each flask of sterile $\mathrm{N}-\mathrm{NaOH}$ or $\mathrm{N}-\mathrm{H}_{2} \mathrm{SO}_{4}$ by means of a sterile pipette; the amount required was estimated experimentally from a single flask.

The subsequent procedure followed that described by Bryde \& Woodcock (1957).

\section{RESULTS}

Identification of metabolites. The metabolism of four unsubstituted and two hydroxylated $\omega$-(2naphthyloxy)- $n$-alkylcarboxylic acids was studied. Unchanged acid was detected in each instance. Table 1 summarizes the identification of the principal metabolites. In a typical experiment in which $\delta$-(2-naphthyloxy)-n-valeric acid (220 mg.) in $0.01 \mathrm{M}-\mathrm{Na}_{2} \mathrm{HPO}_{4}(1800 \mathrm{ml}$.) was incubated with $S$. laxa, $46 \mathrm{mg}$. of $\beta$-(2-naphthyloxy)propionic acid, together with $45 \mathrm{mg}$. of unchanged acid, was isolated by large-scale paper chromatography as described previously (Byrde et al. 1956). Since $\beta$-naphthol was present in trace amounts only, after being washed with aqueous $\mathrm{NaHCO}_{3}$ the ethereal extracts from a number of experiments were combined to obtain a specimen for mixed m.p. determination.

Fungitoxicity in vitro. The growth of S. laxa in glucose-peptone-phosphate agar in the presence of ethanol $(1 \%, v / v)$ and a series of $\omega \cdot(2$-naphthyloxy)- $n$-alkylcarboxylic acids $(0.25 \mathrm{~mm})$ is shown in Table 2.

Since the $\mathrm{p} K_{a}$ value of 2-naphthyloxyacetic acid is 3.7 (Byrde et al. 1956), the more reliable comparison of fungistatic activity is that at $\mathrm{pH} 2 \cdot 7$, where the acids are predominantly undissociated (Simon \& Blackman, 1949). The higher $\mathrm{pH}$ level 
Table 1. Identification of principal metabolites of $\omega$-(2-naphthyloxy)-n-alkylcarboxylic acids incubated with Sclerotinia laxa

The $R_{F}$ values were obtained with butanol-ethanol-aq. $3 \mathrm{~N}$-ammonia (4:1:5, by vol.)

\begin{tabular}{|c|c|c|c|c|}
\hline Substrate & Metabolites & M.p. & $R_{F}$ & Identification \\
\hline 2-Naphthyloxyacetic acid & None* & - & - & - \\
\hline$\beta$-(2-Naphthyloxy)propionic acid & $\begin{array}{l}\beta \text {-Naphthol } \\
\text { Unknown compound (I) }\end{array}$ & $\begin{array}{c}119-120^{\circ} \\
-\end{array}$ & $\begin{array}{l}0.91 \\
0.48\end{array}$ & Mixed m.p. \\
\hline$\gamma$-(2-Naphthyloxy)- $n$-butyric acid & 2-Naphthyloxyacetic acid & $153-154^{\circ}$ & 0.64 & Mixed m.p. \\
\hline$\delta$-(2-Naphthyloxy)- $n$-valeric acid & $\begin{array}{l}\beta \text {-(2-Naphthyloxy)propionic acid } \\
\beta \text {-Naphthol } \\
\text { Unknown compound (I) }\end{array}$ & $\begin{array}{c}141-142^{\circ} \\
- \\
-\end{array}$ & $\begin{array}{l}0.67 \\
0.92 \\
0.48\end{array}$ & $\begin{array}{l}\text { Mixed m.p. } \\
R_{F}\end{array}$ \\
\hline $\begin{array}{l}\beta-(6-H y d r o x y-2-n a p h t h y l o x y)- \\
\text { propionic acid }\end{array}$ & $\begin{array}{l}\text { Two unknown acidic compounds } \\
\text { (II, III) }\end{array}$ & - & $\left\{\begin{array}{l}0 \cdot 25 \text { (II) } \\
0 \cdot 35 \text { (III) }\end{array}\right.$ & - \\
\hline $\begin{array}{l}\gamma \text {-(6-Hydroxy-2-naphthyloxy)- } \\
n \text {-butyric acid }\end{array}$ & $\begin{array}{l}\text { 6-Hydroxy-2-naphthyloxy- } \\
\text { acetic acid }\end{array}$ & - & $0 \cdot 37$ & $R_{F}$ \\
\hline
\end{tabular}

* Trace of 6-hydroxy-2-naphthyloxyacetic acid detected chromatographically in two out of five experiments.

Table 2. Fungistatic activity towards S. laxa of acids of the general formula $\mathrm{C}_{10} \mathrm{H}_{7} \cdot \mathrm{O} \cdot\left[\mathrm{CH}_{2}\right]_{n} \cdot \mathrm{CO}_{2} \mathrm{H}$ $(0.25 \mathrm{mM})$ in glucose-peptone-phosphate medium

\begin{tabular}{ccc} 
& \multicolumn{2}{c}{$\begin{array}{c}\text { Mean growth rate } \\
\text { (mm./day) }\end{array}$} \\
$\overbrace{\mathrm{pH} 2 \cdot 7}^{\mathrm{pH} \mathrm{7.0}}$ \\
1 & $0 \cdot 03$ & $17 \cdot 69$ \\
2 & $0 \cdot 00$ & $6 \cdot 19$ \\
3 & $0 \cdot 00$ & $5 \cdot 25$ \\
4 & $1 \cdot 75$ & $7 \cdot 07$ \\
5 & $1 \cdot 60$ & $6 \cdot 50$ \\
6 & $4 \cdot 60$ & $15 \cdot 07$ \\
7 & $4 \cdot 20$ & $11 \cdot 13$ \\
Control & $7 \cdot 72$ & $19 \cdot 75$ \\
Least significant & 1.51 & $5 \cdot 16$ \\
difference $(P=0.05)$ & &
\end{tabular}

approaches that of the detoxication experiments. The effect of pH on the activity of 2-naphthyloxyacetic acid is particularly marked.

In subsequent experiments the fungistatic activity towards $S$. laxa of $\beta$-(2-naphthyloxy)propionic acid and its detoxication product, $\beta$ naphthol, were compared at two pH levels. The growth-rate data are summarized in Table 3, and the dose-response data, obtained by the probit method for quantitative analysis (Finney, 1952), in Table 4.

\section{DISCUSSION}

Although the metabolism of the $\omega$-(2-naphthyloxy)$n$-alkylcarboxylic acids by $A$. niger involved nuclear hydroxylation, followed by $\beta$-oxidation of the side chain, the former process was rarely encountered in the present work with S. laxa. Moreover, the presence of substantial quantities of unchanged acids after 7 days' incubation with the fungus indicates a comparatively low rate of $\beta$ oxidation. Despite this poor breakdown, $\beta$ naphthol was isolated in small amount from $\beta$-(2- naphthyloxy)propionic acid and also detected chromatographically from $\delta$-(2-naphthyloxy)- $n$ valeric acid.

These results are analogous to those of Fawcett, Ingram \& Wain (1954), who obtained phenol from flax plants which had been treated with the corresponding phenoxy-n-alkylcarboxylic acids, but offer a marked contrast with previous work in which the propionic acid side chain resisted $\beta$ oxidation by $A$. niger (Byrde et al. 1956; Byrde \& Woodcock, 1957). It is significant that when $\beta-(6-$

Table 3. Mean growth rate of $\mathrm{S}$. laxa mycelium in the presence of $\beta$-(2-naphthyloxy)propionic acid and $\beta$-naphthol at two $\mathrm{pH}$ levels

Conditions were as described in the text

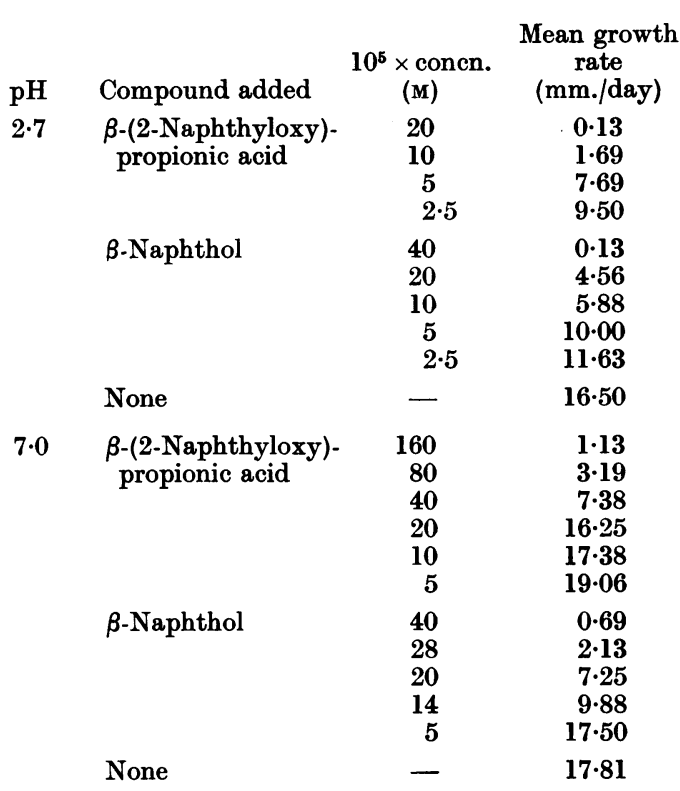


Table 4. Dose-response data derived from Table 3

\begin{tabular}{|c|c|c|c|c|c|}
\hline $\mathrm{pH}$ & Compound & $\begin{array}{l}\text { Equation of probit } \\
\text { regression line }\end{array}$ & $10^{5} \underset{(\mathrm{M})}{\mathrm{ED}_{50}}{ }^{*}$ & $\begin{array}{l}\text { Slope of probit } \\
\text { regression line }\end{array}$ & $\begin{array}{l}\text { Relative } \\
\text { potency* }\end{array}$ \\
\hline $2 \cdot 7$ & $\beta$-(2-Naphthyloxy)propionic acid & $Y=6 \cdot 11-1 \cdot 89 x$ & $\begin{array}{c}3 \cdot 88 \\
(1 \cdot 82-6 \cdot 64)\end{array}$ & $-1 \cdot 89 \pm 0 \cdot 33$ & $100 \cdot 0$ \\
\hline & $\beta$-Naphthol & $Y=6 \cdot 65-1 \cdot 89 x$ & $\begin{array}{c}7 \cdot 48 \\
(3 \cdot 68-11 \cdot 99)\end{array}$ & $-1 \cdot 89 \pm 0 \cdot 33$ & $\begin{array}{c}51 \cdot 6 \\
(27 \cdot 3-100 \cdot 6)\end{array}$ \\
\hline $7 \cdot 0$ & $\beta$-(2-Naphthyloxy)propionic acid & $Y=10.54-3.45 x$ & $\begin{array}{c}434 \\
(33 \cdot 7-53 \cdot 8)\end{array}$ & $-3 \cdot 45 \pm 0 \cdot 52$ & $\dagger$ \\
\hline & $\beta$-Naphthol & $Y=10 \cdot 14-4 \cdot 23 x$ & $\begin{array}{c}16 \cdot 4 \\
(14 \cdot 0-21 \cdot 2)\end{array}$ & $-4 \cdot 23 \pm 0 \cdot 85$ & $\dagger$ \\
\hline
\end{tabular}

hydroxy-2-naphthyloxy)propionic acid was incubated with $S$. laxa no 2:6-dihydroxynaphthalene was detected, which suggests that the retention of an intact propionic acid side chain may be associated with the presence of a hydroxyl group in position 6. The presence of the acidic compounds (II) and (III) referred to in Table 1 suggests that fission of the hydroxyl-containing ring has taken place to some extent. A similar breakdown of 2 methoxynaphthalene by $A$. niger and $S$. laxa has recently been encountered (R. J. W. Byrde, D. F. Downing \& D. Woodcock, unpublished work).

The activity of the $\omega$-(2-naphthyloxy)-n-alkylcarboxylic acids $\mathrm{C}_{10} \mathrm{H}_{7} \cdot \mathrm{O} \cdot\left[\mathrm{CH}_{2}\right]_{n} \cdot \mathrm{CO}_{2} \mathrm{H}$ against $S$. laxa followed a similar pattern to that shown against $A$. niger with a peak in activity at $n=2-3$. It follows that the conversion of $\gamma$-(2-naphthyloxy)$n$-butyric acid into the corresponding acetic acid is accompanied by a decrease in activity against $S$. laxa. In comparisons of the activities of $\beta-(2-$ naphthyloxy)propionic acid and $\beta$-naphthol, the former was the more active at $\mathrm{pH} 2.7$ where both compounds are present as undissociated molecules. At $\mathrm{pH} 7 \cdot 0$, however, the acid, which is largely present as the anion, was less active than the naphthol, and hence the conversion of $\beta-(2-$ naphthyloxy)propionic acid into $\beta$-naphthol at $\mathrm{pH} 8 \cdot 1$ is likely to be accompanied by an increase in activity. Because of the relatively small amounts of acid which are metabolized, this is unlikely to play an important part in its fungistatic activity towards S. laxa.

\section{SUMMARY}

1. By the use of Sclerotinia laxa in a replacementculture technique, $\gamma$-(2-naphthyloxy)- $n$-butyric and $\delta$-(2-naphthyloxy)- $n$-valeric acids underwent $\beta$ oxidation to the corresponding acetic and propionic acids respectively.

2. Similarly, $\beta$-naphthol was isolated in small amounts from $\beta$-(2-naphthyloxy)propionic acid; the fungistatic activity of the former was higher at pH 7 but lower at $\mathrm{pH} 2 \cdot 7$.

3. Nuclear hydroxylation by $S$. laxa was virtually absent.

The authors wish to thank Mr G. M. Clarke for statistical advice and Miss M. Waller and Miss N. Waugh for valuable technical assistance.

\section{REFERENCES}

Byrde, R. J. W., Harris, J. F. \& Woodcock, D. (1956). Biochem. J. 64, 154.

Byrde, R.J. W. \& Woodcock, D. (1957). Biochem.J.65, 682.

Fawcett, C. H., Ingram, J. M. A. \& Wain, R. L. (1954). Proc. Roy. Soc. B, 142, 60.

Finney, D. J. (1952). Probit Analysis. Cambridge University Press.

Simon, E. W. \& Blackman, G. E. (1949). Rep. 3rd Symp. Soc. exp. Biol. p. 253. 